András Nagy, Kaposvári egyetem

\title{
NÁNDOR BirHer - PÉTER BERTALAN: \\ Hálózatokban (In Networks) \\ Oktker-Nodus Kiadó, Veszprém, 2014. 221 p.
}

Arriving to the $21^{\text {st }}$ century it became more clear, that a new approach is needed for the understanding and even predictability of social processes, that is, to think in networks. Network theory is a new tool in the hands of mankind, with which, if used properly, we can find answers to the relevant questions concerning our existence and security, whether it is cancer research or the events taking place in Ukraine or in the Middle East.

We need to run faster in order to stay in place - writes Thomas L. Friedman in his work The world is flat. The network theory not only makes it possible to stay in place, but also makes the future more predictable and clear, but of course not like a weather forecast. Nowadays it is often expressed, that everything is connected. It makes more and more sense.

In the book of Nándor Birher and Péter Bertalan, In networks, published in 2014, the network law theory is presented with the background of law theory and philosophy of law. "The task of thinking in networks is to reveal those key players in the society, the help of whom those patterns are created, which - by the formalized law - are expressed as rule of law and practice of law. " 66 In the first chapters of the book the reader can have a look at the most important theories of legal theory and philosophy of law, which determine the development of legal systems and social networks of nowadays, those processes are presented in detail, which led the authors to the concept of network law theory.

In the writing the possible solutions for the questions of education and employment of the Roma and Gypsies are examined with novel methods. The mapping of connection network of keywords of norms provides a deeper analysis. The quantitative text analysis, as a possibility for predicting with the use of keywords in the process of law-making and the application of the law is presented.

The dynamic development and adaptability of networks is remarkable, this is especially true for the organization of the Catholic Church. "The apparent stability and flexible adaptability of this institution is derived from the dichotomy of its structure: on one hand, the multi-centric and hierarchic structure, on the other hand the vertical structural form makes plastic-like its operation, to always be able to withstand the storms of history and the social

\footnotetext{
${ }^{66}$ Nándor Birher - Péter Bertalan: Hálózatokban. Oktker-Nodus Kiadó, Veszprém, 2014. 72. p.
} 
changes. ${ }^{, 67}$ from We can be the witnesses of the clash of the Catholic Church and the State Security Services in the chapter titled: Clash of Networks, where there are primery sources used from the Historical Archives of the State Security Services, and the introduction of the less known Provida Mater Encyclic apostolic Constitution.

In the study, titled: On the edge of historical networks the socio-political importance of the Roma are in the foreground. The chapter, titled: On the edge of social networks is about the Roma ethnic groups as smaller communities of the society, examining the networks determining their mechanisms of integration, approaching the question objectively and scientifically. This issue in Hungary is often not free from misinterpretation and emotions.

The book not only provides intellectual and thought-provoking journey to the world of networks for those, who knows well the work of Hakan Hakansson, Nicholas A. Christakis, James H. Fowler, or Albert-László Barabási, but also for those, who want to get to know the complex connection system of social processes and social networks, those links, which determine our everyday life, and surrounds us.

\section{„Time is a stream that bears or covers you:}

\section{A man may swim in it but not direct it."}

The thoughts of Imre Madách are reflected in the born of the homo dictios. Our embeddedness in the network of connections determine our decisions in business, in political and in private life as well. The individuals are embedded in the network of connections of the society, the states, trans- and multinational companies, international organizations are embedded in the international system. The man of the $21^{\text {st }}$ century can be compared to a spider tangled into its own web.

Nándor Birher and Péter Bertalan finding the roots of the current social problems with the help of network theory, found solutions in its system of contexts. Concerning the situation of the Roma they see the solution in the process of law-making and urging a closer cooperation between state institutions and civil organizations of interest of the Roma, the parliamentary representation of the Roma free from parties.

"The norm creating ability of man is not the result of ratio, and not of some elusive nature, but simply an evolutionary necessity, which ensure that we get along better together. Only life can legitimize the rules. For 6-7 billion to be able to live on the planet at the same time, very discerning network coordination is needed. A new evolutionary situation has arisen. The spirit in this new situation gave us new tools in order to survive. The system theories and the

\footnotetext{
${ }^{67}$ ib. 143. p.
} 
technologies attached to them belong to these. If we are able to use them properly, many of us

- live more creatively, stronger and happier. If not, we will inevitably deplete our future."68

Joining forces and cooperation are inevitable not only to deal with social problems, but also to manage international conflicts. The news in the public media can lead us astray, if we do not sense the processes and the reality of networks behind the events. I recommend the book for those, who would like to get acquainted with the world of social networks, and for those, who looks at it through the lens of the scientists, as the researches carried out in the book are suggestive. The book was compiled by two authors working in two different disciplines, along clear and logical way of thinking. For the easier understanding, at many points there are illustrative figures and similes helping the reader to grab the main points of the book. The representatives of the profession and those, who are interested in the topic can read with pleasure this not easy, but meaningful and useful read.

\section{BIRHER NÁNDOR - BERTALAN PÉTER:}

\section{Hálózatokban}

\section{Oktker-Nodus Kiadó, Veszprém, 2014. 221 p.}

A XXI. századba érkezve egyre világosabbá vált, hogy a társadalmi folyamatok megértéséhez, sőt, akár előre jelezhetőségéhez új megközelítésre van szükség, a hálózatokban való gondolkodásra. A hálózatelmélet új eszköz az emberiség kezében, melyet megfelelően használva választ kaphatunk létünk és biztonságunk szempontjából releváns kérdéseinkre, legyen szó akár a rákkutatásról, vagy az Ukrajnában és a Közel-Keleten zajló eseményekről.

„Egyre gyorsabban kell futnunk ahhoz, hogy egy helyben maradhassunk”- írja Thomas L. Friedman „És mégis lapos a Föld” című munkájában. A hálózatelmélet nemcsak az egy helyben maradást teszi lehetővé, hanem a jövőt is könnyebben megjósolhatóvá, világosabbá teszi, de természetesen nem beszélhetünk róla úgy, mint egy időjárás-jelentésről. Napjainkban gyakran emlegetik, hogy minden mindennel összefügg. Ez egyre inkább értelmet nyer.

Birher Nándor és Bertalan Péter 2014-ben megjelent Hálózatokban című könyvében helyet kap a hálózati jogelmélet, széleskörü jogelméleti, jogfilozófiai hátteret bemutatva. „, A hálózati gondolkodás feladata, hogy feltárja azokat a kulcsszereplöket a társadalomban, akik segítségével kialakulnak azok a mintázatok, amelyek - az egyébként már formalizált jog által - jogrendként kimondásra kerülnek és joggyakorlatként megvalósulnak. "69 Az írás első

\footnotetext{
${ }^{68}$ ib. 53.p.

${ }^{69}$ Birher Nándor - Bertalan Péter: Hálózatokban. Oktker-Nodus Kiadó, Veszprém, 2014. 72. p.
} 
fejezeteiben az olvasó betekintést nyerhet a legfontosabb jogelméleti és jogfilozófiai elméletekbe, melyek napjaink jogrendszereinek és társadalmi hálózatainak kialakulását meghatározzák, részletesen bemutatásra kerülnek azok a folyamatok, melyek elvezették a szerzőket a hálózati jogelmélet fogalmához.

A kötetben újszerü módszerekkel vizsgálják a romákkal, cigányokkal kapcsolatos oktatási, foglalkoztatási kérdések megoldási lehetőségeit. A normák kulcsszavainak kapcsolati hálójának feltérképezése mélyebb elemzést tesz lehetővé. Bemutatásra kerül a kvantitatív szövegelemzés, mint előrejelzési lehetőség a jogalkotás és jogalkalmazás folyamatában előforduló kulcsszavak használatával.

A hálózatok dinamikus fejlődése, alkalmazkodó képessége figyelemre méltó, különösen igaz ez a katolikus egyház szervezetére. „Ennek az intézménynek látszólagos stabilitása és rugalmas alkalmazkodása struktúrája kettősségéböl fakad: egyrészt a sokcentrumú, hierarchikus szerkezet, másrészt a vertikális szerkezeti felépítés teszi plasztikussá úgy müködését, hogy a történelem viharait és a társadalom változásait mindig ki tudta állni. ",70 A katolikus egyház és az állambiztonsági szervek küzdelmének lehetünk tanúi a Hálózatok harca című fejezetben, az Állambiztonsági Szolgálatok Történeti Levéltárából származó primer források felhasználásával, valamint a kevesek által ismert Provida Mater kezdetű apostoli konstitúció Magyarországi utóéletének bemutatásával.

A történelmi hálózatok peremén címủ tanulmányban a cigányság társadalompolitikai fontossága kerül előtérbe. A társadalmi hálózatok peremén címet viselő fejezet a társadalom kisebb közösségein belül a roma etnikum integrálódási mechanizmusait meghatározó hálózatok vizsgálatáról szól, objektíven, tudományos szempontból megközelítve a Magyarországon gyakran indulatoktól és félreértelmezésektől sem mentes kérdéskört.

A könyv nemcsak azoknak nyújt intellektuális, gondolatébresztő utazást a hálózatok világába, akik jól ismerik Hakan Hakansson, Nicholas A. Christakis, James H. Fowler, vagy Barabási Albert-László munkásságát, hanem azoknak is, akik meg szeretnék ismerni a társadalmi folyamatok, társadalmi hálózatok komplex kapcsolatrendszerét, azokat az összefüggéseket, melyek mindennapjainkat meghatározzák, körülvesznek minket.

„A kor folyam, mely visz vagy elmerit,

úszója, nem vezére az egyén”

Madách Imre gondolatai tükröződnek a hálózati ember, a homo diktiosz megszületésében. Kapcsolati hálókba való beágyazottságunk az üzleti, politikai és magánéletben is

\footnotetext{
${ }^{70}$ Uo. 143. p.
} 
meghatározzák döntéseinket. Az egyének a társadalom kapcsolati hálóiba, az államok, transzés multinacionális vállalatok, nemzetközi szervezetek a nemzetközi rendszerbe vannak beágyazva. A XXI. század embere egy olyan pókhoz hasonlítható, ami a saját hálójába gabalyodott bele.

Birher Nándor és Bertalan Péter a jelenlegi társadalmi problémák gyökereit a hálózatelmélet segítségével megkeresve, annak összefüggésrendszerében vizsgálva találnak megoldást. A romák helyzetét tekintve a jogalkotás folyamataiban és a szorosabb együttműködést sürgetve az állam intézményrendszere és a cigányság érdekérvényesítő civil szervezetei között, a cigányság pártoktól mentes parlamenti képviseletében látják.

„Az ember normaalkotó képessége nem a ráció terméke, nem is valamiféle megfoghatatlan természeté, hanem egyszerüen evolúciós szükségszerüség, amely biztositja, hogy együtt könnyebben boldoguljunk. Egyedül az élet legitimálhatja a szabályokat. Ahhoz, hogy 6-7 milliárd ember élni tudjon egy időben a bolygónkon igazán kifinomult hálózati koordinációra van szükség. Új evolúciós helyzet állt elö. A szellem pedig ebben az új helyzetben a túlélés érdekében új eszközöket adott kezünkbe. Ide tartoznak a hálózat-elméletek és az azokhoz kapcsolódó technológiák. Ha képesek vagyunk ezeket jól használni, sokan - azaz: egyre kreatívabban, egyre erösebben, boldogabban élni. Ha nem, akkor elkerülhetetlenül feléljük a jövőnket. "71

Az összefogás és együttmüködés nemcsak a társadalmi problémák, de a nemzetközi konfliktusok kezeléséhez is elengedhetetlen. A médiában, a sajtóban napvilágot látó hírek tévútra csalhatnak, ha nem érzékeljük az események mögötti folyamatok, hálózatok valóságát. Ajánlom a Hálózatokban címü könyvet mindazoknak, akik szeretnének megismerkedni a társadalmi hálózatok világával, és azoknak is, akik a kutató szemüvegén keresztül tekintenek rá, hisz a müben elvégzett kutatások elgondolkodtatóak.

A könyvet két különböző tudományterületen dolgozó kutató állította össze logikus, világos gondolatmenet alapján. Az értelmezést számos ponton szemléletes hasonlatok és ábrák segítik, közelebb engedve az olvasót a lényeg megragadásához. Érdeklődéssel forgathatják a szakma képviselői és a téma iránt érdeklődők egyaránt a közel sem könnyü, ám annál tartalmasabb és hasznosabb olvasmányt.

\footnotetext{
${ }^{71}$ Uo. 53.p.
} 